\title{
HUKUM ABORSI AKIBAT PERKOSAAN (ANALISIS HUKUM ISLAM TERHADAP PERATURAN PEMERINTAH NOMOR 61 TAHUN 2014 TENTANG KESEHATAN REPRODUKSI )
}

\author{
Sabarudin Ahmad \\ Fakultas Syariah IAIN Palangka Raya \\ sabarudin.ahmad@iain-palangkaraya.ac.id
}

Received:31-11-2018; Revised:15-12-2018; Accepted:17-12-2018

\begin{abstract}
The abortion of raping is a new problem of law. On 2014 the Government Law Number 61 year 2014 is legalized about Reproduction Health which permitting the abortion of raping consequence, as the implementer of regulation Number 36 year 2009 about Health. This decision is being a discussion, it is not except through Islamic law. It is because no positive law which permit it. The type of study was normative legal research, where the analysis method was content anlysis, then analyzed by using the theories of Law Regulation, Human Right, Justice, and Maqāsid Syarī'ah.Result of the study were the Government Law Number 61 year 2014 about Reproduction Health which permitting the abortion of raping consequence because of psycological traumatic of the victim, by some requeremenrs such as the pregnancy is not than 40 days, and apply the safe procedure, qualified, and responsible. While based on the consideration of Islamic law mentioned that the abortion of raping consequence is not permitted, because it is not appreared the Maqāṣid Syarī'ah (hifẓual-nafs and hifẓual-nasl). Besides, this consideration also break the human right and does not show the justice which put aside the embryo's right, because the badness of a woman as raping victim is not at the level of ad-daruriyat, but only on the level of al-häjiyat.
\end{abstract}

Keywords:abortion, rape, and Islamic law.

\section{INTISARI}

Aborsi akibat perkosaan merupakan permasalahan hukum yang baru. Pada tahun 2014 disahkanlah Peraturan Pemerintah Nomor 61 tahun 2014 tentang Kesehatan Reproduksi yang membolehkan aborsi akibat perkosaan, sebagai pelaksana dari Undang-Undang Nomor 36 tahun 2009 tentang Kesehatan. Ketentuan ini menjadi perdebatan, tidak terkecuali dalam pandangan hukum Islam. Karena sebelumnya belum ada hukum positif yang membolehkannya. Jenis penelitian ini ialah penelitian hukum normatif, metode analisis datanya ialah content analysis, kemudian menelaahnya menggunakan teori Peraturan Perundang-Undangan, teori Hak Asasi Manusia, teori Keadilan, dan teori Maqāșid Syarī'ah.Hasil penelitian ini ialah bahwa Peraturan Pemerintah Nomor 61 tahun 2014 tentang Kesehatan Reproduksi membolehkan aborsi akibat perkosaan karena korban perkosaan mengalami trauma psikolgis, dengan persyarataan kehamilan tidak lebih dari 40 hari, dan diselenggarakan dengan prosedur yang aman, bermutu, dan bertanggung jawab. Sedangkan ditinjau dari hukum Islam hasilnya ialah bahwa aborsi akibat perkosaan tidak diperbolehkan, karena tidak terwujudnya Maqāșid Syarīah (hifẓual-nafs dan hifẓual-nasl). Selain itu, ketentuan ini juga melanggar hak asasi manusia dan tidak 
mencerminkan keadilan, yang telah mengesampingkan hak-hak janin, padahal kemudaratan perempuan korban perkosaan tidak sampai pada tingkatan ad-daruriyat, hanya tingkatan alhâjjiyat.

Kata Kunci:aborsi, perkosaan dan hukum Islam.

\section{A. Pendahuluan}

Indonesia merupakan negara dengan angka aborsi cukup tinggi. Hal ini dapat dilihat dari berbagai berita di media masa, baik cetak maupun elektronik. Terhitung sejak tahun 2012 hingga bulan Juli tahun 2014, kasus aborsi di Indonesia mencapai 2,5 juta kasus pertahun. Sehingga kasus aborsi dalam sehari berjumlah sekitar 6800 kasus. Bahkan 30 persen pelakunya merupakan remaja SMP dan SMA. ${ }^{1}$ Gambaran tersebut menunjukkan bahwa aborsi merupakan masalah yang serius dan fenomenal.

Praktik aborsi ini cenderung meningkat tiap tahunnya. Menurut Sugiri Syarif, kepala Badan Kependudukan dan Keluarga Berencana Nasional (BKKBN) bahwa "Secara khusus kita memang tidak punya angka aborsi di Indonesia. Tapi diduga kasus aborsi trennya meningkat". 2 Untuk mengetahui banyaknya kasus aborsi di Indonesia memang sulit. Frekuensi terjadinya aborsi sangat sulit dihitung secara akurat. Karena aborsi buatan sering terjadi tanpa dilaporkan. Kecuali terjadi komplikasi, sehingga perlu perawatan di rumah sakit. ${ }^{3}$ Berdasarkan dari beberapa data di atas, meskipun angkanya tidak pasti, tetapi dapat diketahui rata-rata kasus aborsi di Indonesia sebanyak 2,5 juta kasus pertahun. Selain itu, yang membuat prihatin ialah bahwa aborsi sebagiannya banyak dilakukan oleh remaja. Sedangkan remaja merupakan harapan untuk membangun sebuah bangsa.

Aborsi dalam hukum positif merupakan perbuatan yang dilarang sebagai suatu tindak pidana. Pasal 346 Kitab Undang-Undang Hukum Pidana (KUHP) menentukan bahwa "Seorang wanita yang sengaja menggugurkan atau mematikan kandungannya atau menyuruh orang lain untuk itu, diancam dengan pidana penjara paling lama empat tahun". ${ }^{4}$ Aborsi dilarang secara tegas dalam KUHP tanpa pengecualian. Namun, pada perkembangannya hukum aborsi lebih longgar, sebagaimana diatur dalam Undang-Undang Nomor 36 tahun 2009 tentang Kesehatan (selanjutnya disebut UU Kesehatan) Pasal 75:

1) Setiap orang dilarang melakukan aborsi. 2) Larangan sebagaimana dimaksud pada ayat (1) dapat dikecualikan berdasarkan: a) Indikasi kedaruratan medis yang dideteksi sejak usia dini kehamilan, baik yang mengancam nyawa ibu dan/atau janin, yang menderita penyakit genetik berat dan/atau cacat bawaan, maupun yang tidak dapat diperbaiki sehingga menyulitkan bayi tersebut hidup di luar kandungan; atau b) Kehamilan akibat perkosaan yang dapat menyebabkan trauma psikologis bagi korban perkosaan. ${ }^{5}$

${ }^{1}$ Chilmi Ardiantofani, 2014, 30 Persen Kasus Aborsi di Jatim Pelakunya Remaja, Surabayanews.co.id/2014/08/18/3745/30-persen-kasus-aborsi-di-jatim-pelakunya-remaja.html (online 28 Oktober 2014).

${ }^{2}$ Vien Dimyati, 2012, BKKBN: Tiap Tahun , Kasus Aborsi meningkat 15 persen, www.jurnas.com/news/71467/BKKBN-tiap-tahun-kasus-aborsi-meningkat-15-persen--2012/1/sosial-budaya/

kesehatan (online 28 Oktober 2014).

${ }^{3}$ Statistik Aborsi, www.aborsi.org/statistik.html (online 28 Oktober 2014)

${ }^{4}$ Soesilo, KUHP (Kitab Undang-Undang Hukum Pidana) \& KUHAP (Kitab Undang-Undang Hukum Acara Pidana), Yogyakarta: Gama Press, 2008, h. 111.

${ }^{5}$ Undang-Undang R.I. Nomor 36 tahun 2009 tentang Kesehatan \& Undang-Undang R.I. Nomor 44 tahun 2009 tentang Rumah Sakit, Bandung: Citra Umbara, 2012,h. 28. 
Aborsi secara umum diatur dalam KUHP, namun menurut asas lex posteriore derogat lex priori ${ }^{6}$,UU Kesehatan yang berlaku belakangan membatalkan peraturan yang terdahulu. Ketentuan ini lebih rinci diatur dalam Peraturan Pemerintah Nomor 61 tahun 2014 tentang Kesehatan Reproduksi (selanjutnya disebut PP/61/2014) sebagai pelaksana dari UU Kesehatan. Oleh karena itu, penelitian akan memfokuskan pada kajian terhadap PP tersebut yang ditinjau dalam perspektif hukum Islam.

Aborsi atas dasar indikasi kedaruratan medis sudah banyak didiskusikan oleh pakar hukum, baik hukum umum maupun hukum Islam,yang mana hukumnya diperbolehkan. Namun untuk aborsi akibat perkosaan cukup mengundang kontroversi, ketentuan semacam ini belum pernah ada sebelumnya. Hukum aborsi akibat perkosaan menarik untuk dikaji lebih dalam. Pro kontra terhadap ketentuan ini terjadi baik kalangan masyarakat umum maupun para akademisi. Penulis terdorong untuk melakukan kajian mendalam terhadap hukum aborsi akibat perkosaan, yang secara khusus dikaji berdasarkan perspektif hukum Islam.

\section{B. Metode Penelitian}

Jenis penelitian ini ialah penelitian hukum normatif. ${ }^{7}$ Hukum dikonsepkan sebagai apa yang tertulis dalam peraturan perundang-undangan (law in book) atau hukum dikonsepkan sebagai kaidah atau norma yang merupakan patokan berperilaku manusia. ${ }^{8}$ Bahan primer dalam penelitian ini berupa al-Qur'ān, Hadis Nabi Muhammad Saw, Peraturan Pemerintah No. 61 tahun 2014 tentang Kesehatan Reproduksi. Kemudian dilengkapi dengan bahan sekunder berupa buku-buku yang terkait bahasan dan bahan tersier. Sedangkan metode analisis data menggunakan metode analisis isi (content analysis). ${ }^{9}$

\section{Hasil dan Pembahasan}

\section{Hukum Aborsi Akibat Perkosaan dalam Peraturan Pemerintah Nomor 61 Tahun} 2014 tentang Kesehatan Reproduksi

Aborsi akibat perkosaan merupakan permasalahan yang sudah lama terjadi. Namun dalam kurun waktu sebelum tahun 2009, belum ada hukum postif di Indonesia yang membolehkan aborsi akibat perkosaan. Baik dalam Kitab Undang-Undang Hukum Pidana (KUHP), ${ }^{10}$ maupun Undang-Undang No. 23 tahun 1992 tentang Kesehatan.

Hukum aborsi di Indonesia dewasa ini telah mengalami perkembangan. Pada tahun 2009, disahkanlah UU No. 36 tahun 2009 tentang Kesehatan sebagai ganti UU No. 23 tahun 1992 tentang Kesehatan,karena tidak lagi sesuai dengan perkembangan, tuntutan, dan kebutuhan hukum dalam masyarakat. UU No. 36 tahun 2009 tentang Kesehatan (UU Kesehatan) pada Pasal 75 ayat (1) menentukan bahwa "setiap orang dilarang melakukan aborsi."

${ }^{6}$ lex posteriore derogat lex priori adalah suatu asas yang berisi bahwa undang-undang lain (yang lebih dahulu berlaku) di mana diatur suatu hal tertentu, tidak berlaku lagi jika ada undang-undang baru (yang berlakunya belakangan) yang mengatur pula hal tertentu tersebut. Lihat C.S.T. Kansil, Pengantar Ilmu Hukum Indonesia, Jakarta: Rineka Cipta, 2011., h. 151.

${ }^{7}$ Soerjono Soekanto dan Sri Mamudji, Penelitian Hukum Normatif, Jakarta: RajaGrafindo Persada, 2003 , h. 13-14.

${ }^{8}$ Amiruddin dan Zainal Asikin, Pengantar Metode Penelitian Hukum, Jakarta: Rajawali Pers, 2010, h. 118.

${ }^{9}$ Analisis isi merupakan suatu analisis mendalam yang dapat menggunakan teknik kuantitatif maupun teknik kualitatif terhadap pesan-pesan menggunakan metode ilmiah dan tidak terbatas pada jenis-jenis variabel yang dapat diukur atau konteks tempat pesan-pesan diciptakan atau disajikan. Lihat Emzir, AnalisisData: Metodologi Penelitian Kualitatif, Jakarta: Rajawali Press, 2011, h. 283-284.

${ }^{10}$ Lihat Pasal 346-349 KUHP dalam Soesilo, KUHP, h. 111-112.

${ }^{11}$ Undang-Undang R.I. Nomor 36 tahun 2009 tentang Kesehatan \& Undang-Undang R.I. Nomor 44 tahun 2009 tentang Rumah Sakit, Bandung: Citra Umbara, 2012, h. 28. 
tetap dilarang, tetapi terdapat pengecualiannya, yaitu aborsi karena indikasi medis dan aborsi akibat perkosaan. Sebagaimana ditentukan dalam Pasal 75 ayat (2):

Larangan sebagaimana dimaksud pada ayat (1) dapat dikecualikan berdasarkan:

a) Indikasi kedaruratan medis yang dideteksi sejak usia dini kehamilan, baik yang mengancam nyawa ibu dan/atau janin, yang menderita penyakit genetik berat dan/atau cacat bawaan, maupun yang tidak dapat diperbaiki sehingga menyulitkan bayi tersebut hidup di luar kandungan; atau

b) Kehamilan akibat perkosaan yang dapat menyebabkan trauma psikologis bagi korban perkosaan. $^{12}$

UU Kesehatan Pasal 75 ayat (2) mengatur tentang pengecualiannya aborsi, yaitu indikasi kedaruratan medis dan akibat perkosaan. aborsi akibat perkosaan menjadi pengecualian merupakan hal yang baru dalam peraturan perundang-undangan di Indonesia. Selanjutnya, pada Pasal 75 ayat (4) ditentukan bahwa "Ketentuan lebih lanjut mengenai indikasi kedaruratan medis dan perkosaan, ...diatur dengan Peraturan Pemerintah". ${ }^{13}$

UU Kesehatan telah mengamanahkan aturan lebih lanjut mengenai pengecualian aborsi pada Peraturan Pemerintah. Amanah ini baru terealisasi pada tahun 2014, yakni dengan disahkannya PP/61/2014 tentang Kesehatan Reproduksi oleh Presiden Susilo Bambang Yudhoyono. Pada Pasal 31 PP/61/2014 ditentukan bahwa:

1) Tindakan aborsi hanya dapat dilakukan berdasarkan:

a. Indikasi kedaruratan medis; atau

b. Kehamilan akibat perkosaan

2) Tindakan aborsi akibat perkosaan sebagaimana dimaksud pada ayat (1) huruf b hanya dapat dilakukan apabila usia kehamilan paling lama berusia 40 (empat puluh) hari dihitung sejak hari pertama haid terakhir. ${ }^{14}$

Berdasarkan Pasal 31 di atas dapat diketahui dengan jelas, bahwa PP/61/2014 telah sesuai dengan amanah UU Kesehatan. Namun, ada sedikit perbedaan mengenai ketentuan usia paling lama kehamilan. Jika di dalam UU Kesehatan menetukan selama enam minggu (42 hari). Sedangkan dalam PP/61/2014 menentukan paling lama 40 hari.

PP/61/2014 selanjutnya menetukan mengenai pembuktian aborsi akibat perkosaan. Karena mengatur tentang kehamilan akibat perkosaan, maka diperlukan ukuran untuk membuktikan kebenaran kehamilan yang terjadi. Apakah memang benar karena diperkosa atau tidak. Ketentuan ini dapat dilihat pada Pasal 34, yaitu:

1) Kehamilan akibat perkosaan sebagaimana dimaksud dalam Pasal 31 ayat (1) huruf b merupakan kehamilan hasil hubungan seksual tanpa adanya persetujuan dari pihak perempuan sesuai dengan ketentuan peraturan perundang-undangan.

2) Kehamilan akibat perkosaan sebagaimana dimaksud pada ayat (1) dibuktikan dengan:

a. Usia kehamilan sesuai dengan kejadian perkosaan, yang dinyatakan oleh surat keterangan dokter; dan

b. Keterangan penyidik, psikolog, dan/atau ahli lain mengenai adanya dugaan perkosaan. $^{15}$

\footnotetext{
${ }^{12}$ Ibid., h. 28-29.

${ }^{13}$ Ibid., h. 29.

${ }^{14}$ Himpunan Peraturan Perundang-Undangan; Undang-Undang Kesehatan dan Kesehatan Jiwa, Bandung: Fokusmedia, 2014, 130.
} 
Aborsi akibat perkosaan hanya dapat dilakukan jika dibuktikan bahwa usia kehamilan tidak melebihi dari 40 hari usia kehamilan. Pembuktian ini harus dari keterangan dokter melalui Surat Keterangan. Selain itu, ditambah dengan keterangan ahli lain seperti penyidik, psikolog dan ahli lainnya. Menurut penjelasan PP/61/2014 yang dimaksud dengan ahli lain adalah dokter spesialis psikiatri, dokter spesialis forensik, dan pekerja sosial. ${ }^{16}$

Aborsi akibat perkosaan dalam penyelenggaraanya memiliki standar yang telah ditetapkan PP/61/2014. Dalam hal ini tidak dapat dilakukan oleh sembarangan dokter dan fasilitas yang tidak memiliki standar. Karena aborsi harus dilakukan dengan aman, bermutu, dan bertanggung jawab. Pada Pasal 35 PP/61/2014 ditentukan:

1) Aborsi berdasarkan indikasi kedaruratan medis dan kehamilan akibat perkosaan harus dilakukan dengan aman, bermutu, dan bertanggung jawab.

2) Praktik aborsi yang aman, bermutu, dan bertanggung jawab sebagaimana dimaksud pada ayat (1) meliputi:

a. Dilakukan oleh dokter sesuai dengan standar;

b. Dilakukan di fasilitas pelayanan kesehatan yang memenuhi syarat yang ditetapkan oleh Menteri;

c. Atas permintaan atau persetujuan perempuan hamil yang bersangkutan;

d. Dengan izin suami, kecuali korban perkosaan;

e. Tidak diskriminatif; dan

f. Tidak mengutamakan imbalan materi.

3) Dalam hal perempuan hamil sebagaimana dimaksud pada ayat (2) huruf c tidak dapat memberikan persetujuan, persetujuan aborsi dapat diberikan oleh keluarga yang bersangkutan.

4) Dalam hal suami tidak dapat dihubungi, izin sebagaimana dimaksud pada ayat (2) huruf d diberikan oleh keluarga yang bersangkutan. ${ }^{17}$

PP/61/2014 menginginkan aborsi dilakukan sesuai standar yang ditentukan. Hal ini karena aborsi yang terjadi di kebanyakan masyarakat dilakukan dengan tidak aman, seperti melalui dukun atau menggunakan obat-obatan tradisional. Oleh karena itu PP/61/2014 mencoba mengatur dengan standar khusus guna menjamin keselamatan pasien. Selain itu, dokter yang melakukan aborsi harus telah mendapatkan pelatihan khusus. Sehingga prinsip aborsi yaitu aman, bermutu, dan bertanggung jawab dapat terlaksana.

\section{Hukum Aborsi Akibat Perkosaan dalam Peraturan Pemerintah Nomor 61 Tahun 2014 ditinjau dari Perspektif Hukum Islam}

Tindak perkosaan merupakan suatu jinayah. Menurut imam Malik hukuman terhadap pelaku pemerkosa dikenai sanksi had. Sementara bagi wanitanya, menurut imam Hanifah dan imam Syafi'i tidak ada sanksi atasnya. ${ }^{18}$ Aborsi akibat perkosaan merupakan isu hukum yang baru. Pada zaman awal Islam secara khusus belum ditemukan permasalahan mengenai aborsi akibat perkosaan. Meskipun demikian, untuk persoalan aborsi secara umum sudah ada. Hal ini dapat dilihat dari kasus terkait dengan aborsi yang terjadi pada masa itu.

\footnotetext{
${ }^{15}$ Ibid., h. 132.

${ }^{16}$ Ibid., h. 161.

${ }^{17}$ Ibid., h. 132-133.

${ }^{18}$ Ibnu Rusyd, Bidayatul Mujtahid Jilid 3, alih bahasa Abdurrahman, Semarang: Asy-Syifa, 1990, h. 632-633.
} 


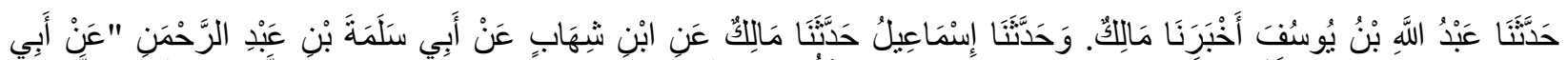

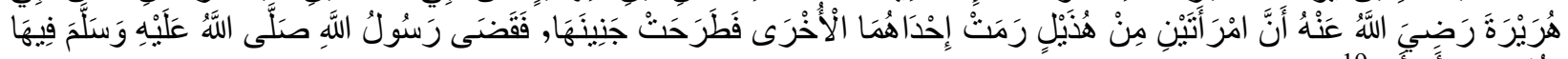

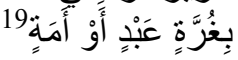

Artinya: Telah menceritakan kepada kami 'Abdullah bin Yusuf. Telah mengabarkan kepada kami Malik dan telah menceritakan kepada kami Isma'il telah menceritakan kepada kami Malik dari Ibnu Syihab dari Abu Salamah bin Abdurrahman dari Abu Hurairah radliallahu 'anhu, ada dua wanita Hudzail, salah satunya memukul yang lain sehingga janin yang dikandung keguguran, dan Rasulullah Shallallahu'alaihiwasallam memutuskan untuk membayar ghurrah, budak laki-laki atau hamba sahaya perempuan. ${ }^{20}$

Kasus di atas menerangkan bahwa telah ada praktik aborsi pada zaman Rasulullah Saw masih hidup. Meskipun tidak secara khusus seperti aborsi yang ada di zaman sekarang ini. Namun secara keseluruhan hadis di atas membicarakan tentang perkelahian yang menyebabkan perempuan suku Hudzail keguguran. Praktik ini jelas dilarang, karena termasuk perbuatan jinayah yang dikenai sanksi denda (diyat).

Hukum Islam melarang dengan tegas segala bentuk pembunuhan tanpa alasan yang dibenarkan, termasuk juga terhadap tindakan aborsi. Allah Swt berfirman dalam Q.S. al-An'am ayat 151:

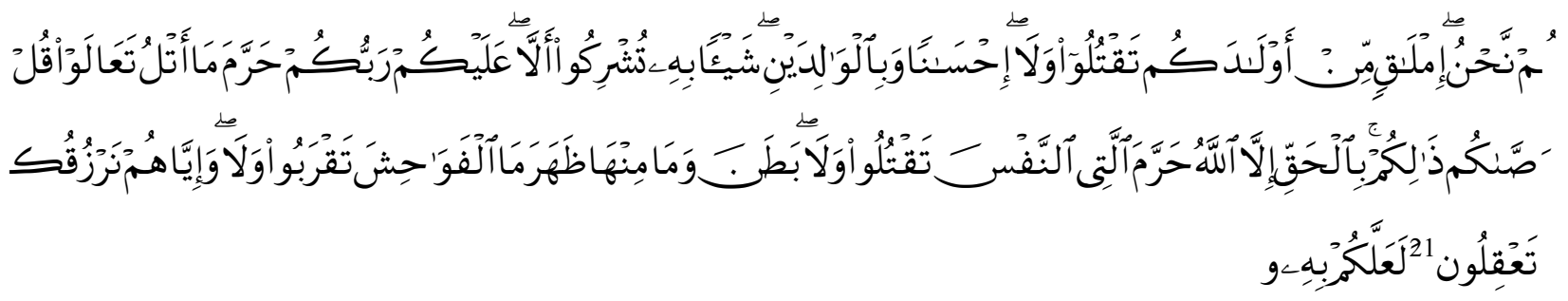

Artinya:Katakanlah (Muhammad), "Marilah aku bacakan apa yang diharamkan Tuhan kepadamu. Jangan mempersekutukan-Nya dengan apapun, berbuat baik kepada ibu bapak, janganlah membunuh anak-anakmu karena miskin. Kamilah yang memberi rezeki kepadamu dan kepada mereka; janganlah mendekati perbuatan keji, baik yang terlihat maupun yang tersembunyi, janglah kamu membunuh orang yang diharamkan Allah kecuali dengan alasan yang benar. Demikianlah Dia memerintahkan kepadamu agar kamu mengerti. ${ }^{22}$

Hukum aborsi akibat perkosaan menurut hukum Islam masih terus menjadi perdebatan. Hal ini terjadi karena tidak ada nas $^{23}$ yang secara khusus mengatur hukum aborsi akibat perkosaan. PP/61/2014 sebagai peraturan-perundang-undangan yang berlaku dan mengikat seluruh masyarakat Indonesia, membolehkan aborsi akibat perkosaan. Menurut mantan Menteri

\footnotetext{
${ }^{19}$ Ahmad bin Ali bin Hajar al-Asqalani, Fathul Baari Juz 12, t.tp., Dar al-Fikr, t.t., h. 246-247.

${ }^{20}$ Terjemahan Kutub at-Tis'ah. Lihat juga Ibnu Hajar Al Asqalani, Fathul Baari 33: Shahih Bukhari, alih bahasa Amir Hamzah, Jakarta: Pustaka Azzam, 2009, h. 675-676.

${ }^{21}$ Al-An'am [6]: 151.

${ }^{22}$ Departemen Agama Republik Indonesia, Al-Qur'an Dan Terjemahnya Juz 1-30 Edisi Baru, Jakarta: Pustaka Agung Harapan, 2006, h. 199.

${ }^{23}$ NaṢ artinya mengangkat atau melahirkan, dalam istilah fikih yaitu sebutan untuk al-Qur'an dan Hadis nabi Muhammad Saw. Lihat Mahmud Yunus, Kamus Arab-Indonesia, Jakarta: Mahmud Yunus Wadzurriyyah, 1990,h. 453.
} 
Kesehatan Nafisah Mboi, yang menjabat sebagai Menteri Kesehatan pada waktu disahkannya PP/61/2014 ini menyatakan bahwa PP/61/2014 mengikuti amanah Undang-Undang Kesehatan dan Fatwa Majelis Ulama (MUI) ${ }^{24}$ Nomor 4 tahun 2005 tentang Aborsi. ${ }^{25}$ Jika dicermati PP/61/2014 memang telah sesuai dengan Fatwa MUI Nomor 4 tahun 2005 tentang Aborsi. PP/61/2014 menentukan bahwa aborsi akibat perkosaan dibolehkan selama masa kehamilan tidak lebih dari 40 hari. Ketentuan ini sesuai dengan Fatwa MUI tentang Aborsi pada ketentuan nomor 2:

Aborsi dibolehkan karena adanya uzur, baik yang bersifat darurat ataupun hajat.

a. Keadaan darurat yang berkaitan dengan kehamilan yang membolehkan aborsi adalah:

1. Perempuan hamil menderita sakit fisik berat seperti kanker stadium lanjut, TBC dengan caverna dan penyakit-penyakit fisik berat lainnya yang harus ditetapkan oleh tim dokter.

2. Dalam keadaan di mana kehamilan mengancam nyawa si ibu.

b. Keadaan hajat yang berkaitan dengan kehamilan yang dapat membolehkan aborsi adalah:

1. Janin yang dikandung dideteksi menderita cacat genetik yang kalau lahir kelak sulit disembuhkan.

2. Kehamilan akibat perkosaan yang ditetapkan oleh Tim yang berwenang yang didalamnya terdapat antara lain keluarga korban, dokter, dan ulama.

c. Kebolehan aborsi sebagimana dimaksud huruf $b$ harus dilakukan sebelum janin berusia 40 hari. $^{26}$

PP/61/2014 dan Fatwa MUI tentang Aborsi membolehkan aborsi akibat perkosaan selama waktu kehamilan tidak lebih dari 40 hari. Dibolehkannya aborsi akibat perkosaan menurut PP/61/2014 karena perempuan korban perkosaan mengalami trauma ${ }^{27}$ psikologis, $^{28}$ sehingga menyulitkan untuk tetap mempertahankan kandungannya. Trauma psikologis secara khusus yang dialami perempuan korban perkosaan ialah sebagaimana yang dikatakan Irma Riyani dalam Jurnalnya yang berjudul Menimbang Kembali Hukum Aborsi Pada Kasus Kehamilan Akibat Perkosaan sebagai berikut:

Bagi perempuan korban perkosaan, tindak perkosaan merupakan sebuah kejadian dan pengalaman yang sangat mengerikan dan meninggalkan trauma yang sangat mendalam, meruntuhkan kepercayaan dan menimbulkan ketidakstabilan emosi. Banyak di antara mereka yang tidak mau berbicara mengenai apa yang telah mereka alami. Aksi diam

\footnotetext{
${ }^{24}$ MUI mulai dibentuk pada tahun 1975. Keanggotaan MUI merupakan golongan dari ulama tradisional dan ulama modern. Sejak saat itu MUI telah mengeluarkan berbagai fatwa-fatwa, baik mengenai upacara keagamaan, pernikahan, kebudayaan, ekonomi, politik, ilmu pengetahuan, maupun kedokteran. Lihat Mohammad Atho Mudzhar, Fatwa-Fatwa Majelis Ulama Indonesia; Sebuah Studi tentang Pemikiran Hukum Islam di Indonesia, alih bahasa Soedarsono, Jakarta: INIS, 1993, h. 5.

${ }^{25}$ Radian Nyi S, 2014, Menkes Tegaskan PP 61/2014 tentang Kesehatan Reproduksi Tak legalkan Aborsi, http://health.detik.com/read/2014/08/19/162817/ 2666595/763/menkes-tegaskan-pp-61-2014-tentang-kesehatanreproduksi-tak-legalkan-aborsi(online 24 Oktober 2014)

${ }^{26}$ Ma'ruf Amin dkk., Himpunan Fatwa Majelis Ulama Indonesia Bidang Sosial dan Budaya, Jakarta: Penerbit Erlangga, 2015, h. 224.

${ }^{27}$ Trauma dalam Kamus Besar Bahasa Indonesia berarti keadaan jiwa atau tingkah laku yang tidak normal sebagai akibat dari tekananan jiwa atau cedera jasmani. Lihat Departemen Pendidikan, Kamus Besar Bahasa Indonesia, Jakarta: Balai Pustaka, 2005, h. 1210.

${ }^{28}$ trauma psikologis adalah keadaan jiwa atau tingkah laku yang tidak normal dan bersifat kejiwaan akibat dari tekanan jiwa atau cedera jasmani.
} 
mereka didasari berbagai alasan. Banyak dari mereka yang merasa malu pada diri sendiri, pada keluarga dan merasa tidak aman terhadap lingkungannya. ...Perkosaan bukan sekedar serangan fisik pada perempuan, tetapi juga serangan terhadap jiwa korban. Hal tersebut bisa menghancurkan kepribadian korban. Dengan demikian, kasus perkosaan merupakan hal serius yang terjadi pada perempuan, keluarganya, dan lingkungan di mana dia tinggal. Baban ditanggung bertambah berat ketika mereka harus menerima kenyataan tentang kemungkinan hamil akibat perkosaan tersebut. ${ }^{29}$

Trauma psikologis (kemudaratan) seperti di atas merupakan pertimbangan hukum dalam menentukan dibolehkannya aborsi akibat perkosaan dalam PP/61/2014. Hukum Islam sendiri mengatur terhadap hal-hal yang memudaratkan dapat membolehkan hal-hal yang diharamkan. Sebagaimana kaidah fikih di bawah ini:

Artinya: "Kemudaratan itu membolehkan hal-hal yang dilarang". 30

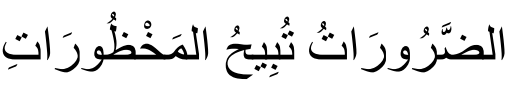

PP/61/2014 membolehkan aborsi akibat perkosaan, karena perempuan yang mengandung janin akibat perkosaan mengalami kemudaratan. Kemudaratannya ialah karena ia menanggung beban trauma psikologis akibat diperkosa seperti telah disebutkan di atas. Hal inilah yang menurut penulis menjadi alasan dibolehkannya aborsi akibat perkosaan. Sejalan dengan itu, MUI juga telah mengeluarkan Fatwa yang membolehkan aborsi akibat perkosaan. Penulis berpendapat bahwa semangat yang terkandung di dalam PP/61/2014 ialah semangat untuk melindungi perempuan korban perkosaan. Harapannya dengan dibolehkannya aborsi akan dapat menghilangkan beban trauma psikolgis yang berat bagi perempuan tersebut. Namun, di sisi lain janin yang dikandungnya tidak bisa dikesampingkan begitu saja. Karena janin juga bentuk awal dari manusia yang perlu dilindungi hak-haknya.

Kaidah fikih di atas yang menentukan kemudaratan membolehkan hal-hal yang dilarang, perlu dipahami mendalam. Menurut Jaih Mubarak pengertian kemudaratan harus diperjelas agar manusia tidak seenaknya melakukan perbuatan yang diharamkan dengan alasan terpaksa atau darurat. $^{31}$ Menurut kalangan ulama ushul fikih yang dikutip oleh A. Djazuli, bahwa kaidah tersebut memiliki persyaratan tertentu, yaitu:

1. Kondisi ad-daruriyat itu mengancam jiwa atau anggota tubuh.

2. Keadaan ad-daruriyat hanya dibolehkan sekedar menghilangkan ad-daruriyatnya dan tidak boleh melampaui batas.

3. Tidak ada jalan lain yang halal kecuali dengan jalan yang dilarang. ${ }^{32}$

Persyaratan inilah yang perlu diperhatikan dalam menetapkan suatu kemudaratan. Syarat pertama mengharuskan kondisi ad-daruriyat yang mengancam jiwa atau anggota tubuh. Dalam hal ini perempuan korban perkosaan jiwanya terancam karena menanggung beban trauma psikologis. Namun ancaman jiwa ini tidak sampai mengakibatkan kematian. Ia hanya menanggung beban psikologis karena telah diperkosa dan hamil. Menurut hemat penulis kondisi ini tidak termasuk dalam kategori aḍ-daruriyatdalam pengkategorianmaqāṣid syarīah, tetapi

\footnotetext{
${ }^{29}$ Irma Riyani, "Menimbang Kembali Hukum Aborsi Pada Kasus Kehamilan Akibat Perkosaan”, Jurnal Studi Agama dan Masyarakat, Palangka Raya: STAIN Palangka Raya, Vol. 2/No. 2, 2005, h. 11-12.

${ }^{30}$ A. Djazuli, Kaidah-Kaidah Fikih: Kaidah-Kaidah Hukum Islam dalam Menyelesaikan Masalah-Masalah yang Praktis, Jakarta: Kencana, 2007, h. 72.

${ }^{31}$ Jaih Mubarok, Kaidah Fiqh: Sejarah dan Kaidah-Kaidah Asasi, Jakarta: RajaGrafindo Persada, 2002, h. 150.

${ }^{32}$ A. Djazuli, Kaidah-Kaidah, h. 72.
} 
masuk dalam kategori al-hājiyat. Muhlish Usman memberikan batasan terhadap ukuran kemudaratan sebagai berikut:

Batasan kemadaratan adalah suatu hal yang mengancam eksistensi manusia, yang terkait dengan panca tujuan, yaitu memelihara agama, memelihara jiwa, memelihara keturunan dan memelihara kehormatan atau harta benda. Dengan demikian darurat itu terkait dengan dharuriah, bukan hajiah dan tahsiniah. ${ }^{33}$

Persyaratan kedua, sebagai contoh ialah ketika seseorang yang hampir sekarat karena sangat kelaparan, kemudian ia hanya menemukan penjual daging babi dan di situ tidak ada makanan lainnya, maka ia diperbolehkan memakan daging babi tersebut hanya sekedarnya, tidak boleh sampai kekenyangan. Dalam kasus aborsi akibat perkosaan, keadaan kemudaratannya ialah perempuan korban perkosaan yang menanggung beban trauma psikologis, diharapkan dengan dilakukannya aborsi akan menghilangkan kemudaratan tersebut. Persyaratan kedua ini telah dirumuskan tersendiri dalam kaidah fikih, yaitu:

Artinya: "Keadaan darurat, ukurannya ditentukan menurut kadar kedaruratannya".34

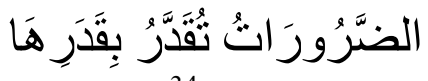

Persyaratan ketiga, dalam kasus aborsi akibat perkosaan menurut PP/61/2014 yaitu tidak ada jalan lain kecuali aborsi. Namun, penulis tidak sependapat, karena masih ada jalan lain yang tidak perlu dengan melakukan aborsi. Jalan tersebut ialah dengan dilakukannya pendampingan dan nasihat kepada perempuan korban perkosaan, sehingga dapat menentramkan hatinya. Selain itu, harus diberikan pemahaman kepada masyarakat bahwa ia adalah korban, dan tidak sepatutnya mendapatkan ejekan dan cemoohan. Kemudian jika ia bersikeras tidak ingin punya anak dari hasil perbuatan perkosaan, maka nanti anak setelah lahir dapat diasuh oleh keluarganya atau oleh panti asuhan. Dalam hal ini penulis sejalan dengan alternatif yang terdapat dalam Pasal 38 PP/61/2014 yaitu:

1) Dalam hal korban perkosaan memutuskan membatalkan keinginan untuk melakukan aborsi setelah mendapatkan informasi mengenai aborsi sebagaimana dimaksud dalam Pasal 37 ayat (3) huruf $d$ atau tidak memenuhi ketentuan untuk dilakukan tindakan aborsi sebagaimana dimaksud dalam Pasal 31 ayat (2), korban perkosaan dapat diberikan pendampingan oleh konselor selama masa kehamilan.

2) Anak yang dilahirkan dari ibu korban perkosaan sebagaimana dimaksud pada ayat (1) dapat diasuh oleh keluarga.

3) Dalam hal keluarga sebagaimana dimaksud pada ayat (2) menolak untuk mengasuh anak yang dilahirkan dari korban perkosaan, anak menjadi anak asuh yang pelaksanaannya dilakukan sesuai dengan ketentuan perundang-undangan. ${ }^{35}$

Penulis berpendapat bahwa karena tidak memenuhi syarat sebagaimana dijelaskan di atas, maka seharusnya aborsi akibat perkosaan dilarang. Sebagai solusinya ialah menggunakan alternatif lain sebagaimana telah dijelaskan sebelumnya. Bahkan solusi ini juga dapat merujuk pada Peraturan Pemerintah No. 40 tahun 2011 tentang Pembinaan, Pendampingan, dan Pemulihan terhadap Anak yang Menjadi Korban atau Pelaku Pornografi ditentukan dalam Pasal 2 ayat (1):

${ }^{33}$ Muhlish Usman, Kaidah-Kaidah Istinbath Hukum Islam: (Kaidah-Kaidah Ushuliyah dan Fiqhiyah), Jakarta: RajaGrafindo Persada, 1995, h. 134.

${ }^{34}$ A. Djazuli, Kaidah-Kaidah, h. 73.

${ }^{35}$ Himpunan Peraturan Perundang-Undangan, h. 134-135. 
1) Setiap anak yang menjadi korban atau pelaku pornografi wajib dibina, didampingi, dan dipulihkan kondisi sosial dan kesehatannya sehingga ia dapat tumbuh berkembang secara sehat.

2) Kewajiban membina, mendampingi dan memulihkan kondisi sosial dan kesehatan anak yang menjadi korban atau pelaku pornografi sebagaimana dimaksud pada ayat (1) dilakasanakan oleh Pemerintah, lembaga sosial, lembaga pendidikan, lembaga keagamaan, keluarga, dan/atau masyarakat.

3) Kewajiban sebagaimana dimaskud pada ayat (2) juga dilaksanakan oleh pemerintah daerah sesuai dengan peraturan perundag-undangan. ${ }^{36}$

Ketentuan di atas merupakan solusi terhadap korban perkosaan. Meskipun yang diatur di dalamnya merupakan anak (maksimal 18 tahun), tetapi bagi yang berusia lebih dari 18 tahun dapat saja penanganannya merujuk pada ketentuan tersebut, atau paling tidak sebagai penguat dari solusi yang penulis sebutkan dalam Pasal 38 PP/61/2014. Pertimbangan hukum lainnya dalam kasus aborsi akibat perkosaan ialah bahwa kemudaratan perempuan korban perkosaan jika dilakukan aborsi, maka akan menimbulkan kemudaratan lain, yaitu bagi janin yang dikandungnya. Padahal maqāssid syarī'ah adalah untuk kemaslahatan, yang salah satunya ialah menjaga jiwa (hifẓual-nafs). Hukum Islam tidak membolehkan menghilangkan kemudaratan dengan kemudaratan lainnya. Hal ini sebagaimana kaidah fikih menentukan:

Artinya: "Kemudaratan tidak boleh dihilangkan dengan kemudaratan lagi". 37

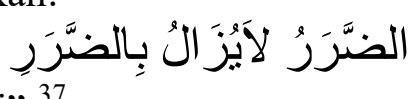

Sesuai dengan kaidah fikih tersebut, maka aborsi akibat perkosaan tidak diperbolehkan. Karena akan menimbulkan kemudaratan yang lainnya. Selain itu, dalam teori maqāșid syarī'ah penulis berpendapat bahwa keadaan ad-daruriyat perempuan korban perkosaan tidak termasuk ke dalam tingkatan aḍ-daruriyat melainkan al-hājiyat. Keadaan al-hājiyat menurut Imam Musbikin ialah keadaan seseorang yang jika tidak segera ditolong, akan menyebabkan kepayahan, tetapi tidak sampai menyebabkan kematian. Dalam keadaan seperti ini, orang tersebut tidak bisa menghalalkan yang haram. ${ }^{38}$

Maqāșid syarī'ah adalah untuk mewujudkan kemaslahatan manusia dengan menjaga lima unsur pokok, yaitu memelihara agama (hifẓuad-din), memelihara jiwa (hifẓual-nafs), memelihara keturunan (hifzual-nasl), memelihara akal (hifẓual-'aql), memelihara harta (hifẓual-māl). ${ }^{39}$ Pemeliharaan kelima unsur pokok dikenal dengan uṣul al-khamsah. Pada permasalahan ini ditekankan pada pemeliharaan jiwa. Untuk mengukur pemeliharaan kelima unsur pokok ini diukur dengan tingkatan kemudaratannya. Sebagaimana disebutkan di atas, bahwa penulis memasukkan kategori kemudaratan perempuan korban perkosaan ke dalam tingkatan al-häjiyat. Untuk lebih jelasnya akan diuraikan ketiga tingkatan tersebut.

1. Maqāșid aḍ-Daruriyat

Maqāșid aḍ-ḍaruriyat adalah kebutuhan manusia yang bersifat primer. Maqāșid aḍdaruriyat dimaksudkan untuk memelihara lima unsur pokok dalam kehidupan manusia. Tidak terjwujudnya aspek ad-daruriyat dapat merusak kehidupan manusia dunia dan akhirat secara

\footnotetext{
${ }^{36}$ Undang-Undang Republik Indonesia Nomor 23, h. 132.

${ }^{37}$ A. Djazuli, Kaidah-Kaidah, h. 73.

${ }^{38}$ Imam Musbikin, Qawa 'id al-Fiqhiyah, Jakarta: RajaGrafindo Persada, 2001, h. 71.

${ }^{39}$ Asfari Jaya Bakri, Konsep Maqaid al-Syari'ah Menurut al-Syatibi, Jakarta: RajaGrafindo Persada, 1996, h.
} 70. 
keseluruhan. ${ }^{40}$ Dalam kasus aborsi akibat perkosaan, jika tidak dilakukan aborsi tidak sampai merusak kehidupan manusia. Beban trauma psikologis yang ditanggung ibu korban perkosaan dapat diatasi dengan jalan lain sebagaimana telah dijelaskan sebelumnya.

2. Maqāṣid al-Hājiyat

Maqāṣid al-hājiyat adalah kebutuhan manusia yang bersifat sekunder. Maqāṣid alhajjiyat dimaksudkan untuk menghilangkan kesulitan atau menjadikan pemeliharan kelima unsur pokok menjadi lebih baik. Tidak terwujudnya maqāssid al-hājiyat tidak sampai merusak keberadaan lima unsur pokok, tetapi akan membawa kepada kesulitan bagi manusia sebagai mukallaf dalam merealisasikannya. ${ }^{41}$ Dalam kasus aborsi akibat perkosaan, perempuan korban perkosaan merasakan kesulitan hidup karena beban trauma psikologis yang ditanggungnya. Sehingga relevan jika kondisi dalam kasus korban perkosaan dimasukkan dalam kategori ini.

3. Maqāṣid at-Taḥsiniyat

Maqāṣid at-taḥsiniyat adalah kebutuhan manusia yang bersifat tersier. Maqāṣid attahsiniyat dimaksudkan agar manusia dapat melakukan yang terbaik untuk penyempurnaan pemeliharaan kelima unsur pokok.. ${ }^{42}$

Penulis dalam hal ini berpendapat, jika dilakukan aborsi terhadap korban perkosaan maka kebutuhan sekunder manusia akan terpenuhi. Artinya terwujudnya kebutuhan al-hājiyat, meskipun masih ada alternatif lain yang telah penulis sebutkan sebelumnya. Namun, jika alternatifnya ialah aborsi maka akan menimbulkan kemudaratan yang lain, yaitu bagi janin yang dikandungnya. Hal ini jelas bertentangan dengan maqāșidsyarī'ah. Kebutuhan dari janin jika dilakukan aborsi masuk kategori tingkatan ad-daruriyat. Karena akan menghilangkan kehidupan janin tersebut. Sekaligus juga tidak terwujudnya unsur yang lain yaitu pemeliharaan keturunan (hifẓunaṣl). Inilah yang seharusnya juga mendapatkan prioritas perlindungan hukum.

Penentuan hukum aborsi akibat perkosaan, dalam hal ini memang ada dua pertimbangan hukum, yaitu pemeliharan jiwa perempuan korban perkosaan dan janin yang dikandungnya. Memelihara jiwa perempuan korban perkosaan agar terhindar dari kesusahan menurut PP/61/2014 yaitu dengan dilakukannya aborsi. Padahal pertimbangan hukum ini seharusnya tidak mengesampingkan hak-hak janin. Meskipun janin dalam hal ini berusia di bawah 40 hari. Namun janin merupakan bentuk awal dari manusia. Sejak terjadinya percampuran antara sprema $^{43}$ dengan ovum ${ }^{44}$ fase kehidupan manusia sudah dimulai. Sebagaimana dikatakan oleh alGhazali dalam bukunya Ihya'Ulumuddin bahwa ketika jatuhnya nutfah (sperma) ke dalam rahim, lalu bercampur dengan ovum, maka dalam hal ini sudah mulai ada kehidupan. ${ }^{45}$ Pendapat alGhazali ini sejalan dengan pendapat ahli kesehatan modern. Menurut Jumrodah dalam jurnalnya yang berjudul Proses Penciptaan Manusia menurut Pandangan Islam dan Embryologi:

Awal kehidupan dalam rahim, menurut para ahli embryologi terjadi dari proses reproduksi yaitu bermula dan berintikan pada konsepsi ialah pertemuan dan pembuahan sel telur wanita atau sperma laki-laki. Sel telur dan sperma dalam Islam dikenal dengan "Nutfah"

\footnotetext{
${ }^{40}$ Ibid., h. 72.

${ }^{41}$ Ibid.

${ }^{42}$ Ibid.

${ }^{43}$ Sperma adalah sel kelamin jantan. Lihat Tim Reality, KamusBiologi, Surabaya: Reality Publisher, 2009 , h.

${ }^{44}$ Ovum adalah sel telur atau sel reproduksi pada wanita. Lihat, Ibid., h. 428.

${ }^{45}$ Imam Ghazali, Ihya'Ulumiddin Jilid 1, alih bahasa Ismail Yakub, Singapura: Pustaka Nasional PTE LTD,
} 533. 1998, h. 1188 . 
yakni setetes cairan tertentu. Itulah bahan atau materi asal manusia, yang sekaligus menjadi titik mula perkembangan dalam rahim, bahwa asal kejadian manusia dari setetes nuthfah, telah dinyatakan dalam al-Qur'an surah an-Nahl ayat: $4 .^{46}$

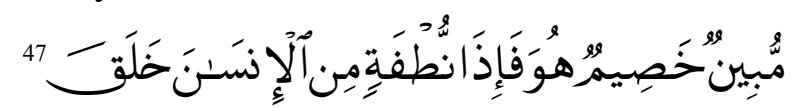

Artinya: "Dia telah menciptakan manusia dari mani, ternyata dia menjadi pembantah yang nyata." 48

Berdasarkan hal di atas, dapat dipahami bahwa fase awal kehidupan manusia telah dimulai sejak terjadinya konsepsi ${ }^{49}$ di dalam rahim. Oleh karena itu, sudah sepatutnya dilindungi keberadaannya sejak fase tersebut. Ketentuan waktu kehamilan tidak boleh lebih dari 40 hari diambil dari pendapat-pendapat ulama fikih. Para ulama fikih empat mazhab ${ }^{50}$ berbeda pendapat dalam permasalahan aborsi. Sebagian menentukan hukumnya dengan mengacu pada waktu peniupan ruh pada janin.

Ahsin W. Alhafidz dalam bukunya Fikih Kesehatan mengatakan bahwa para fuqaha berpendapat perubahan janin menjadi manusia terjadi setelah bulan keempat kehamilan, yaitu terjadinya peniupan ruh kepada janin. Sehingga kebanyakan ulama tidak mengizinkan aborsi setelah kehamilan empat bulan, karena hal itu termasuk jinayah. ${ }^{51}$ Dalam hal ini dapat dikatakan telah terjadi ijma,52 ulama terhadap aborsi setelah kehamilan berusia empat bulan hukumnya ialah haram. Sementara sebelum kehamilan berumur empat bulan para ulama berbeda pendapat.

Para ulama dalam menentukan hukum aborsi berdasarkan waktu peniupan ruh janin ini didasarkan pada hadis Rasulullah Saw sebagai berikut:

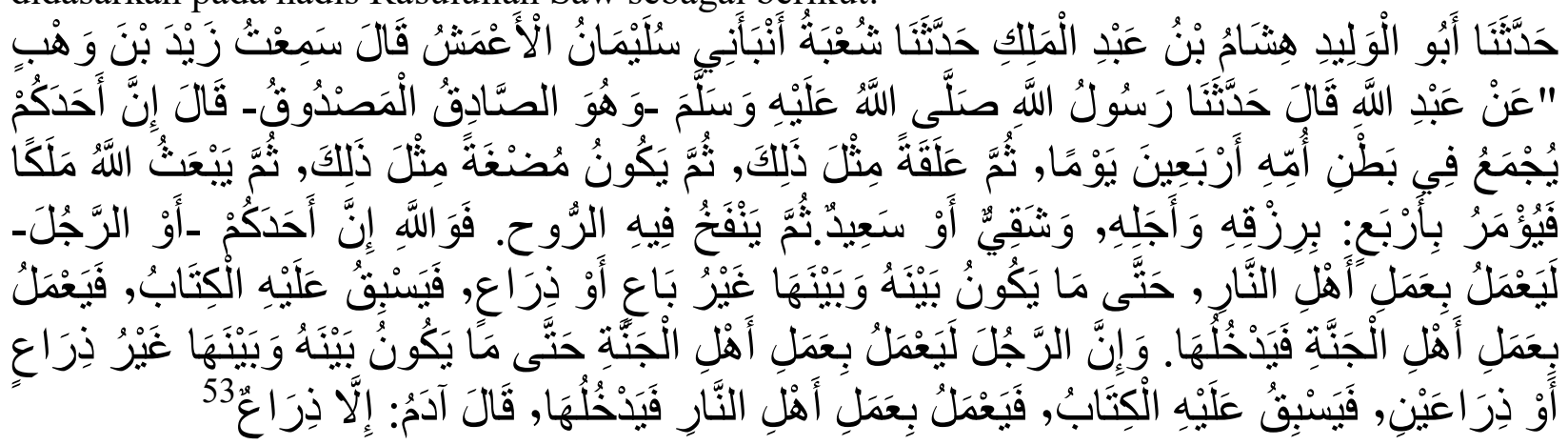

${ }^{46}$ Jumrodah, "Proses Penciptaan Manusia Menurut Pandangan Islam dan Embryologi”, Jurnal Himmah, Palangka Raya: STAIN Palangka Raya, Vol. VII, No. 19, 2006, h. 57. Lihat juga Huzaimah Tahido yanggo, Masail Fiqhiyah; Kajian Hukum Islam Kontemporer, Bandung: Angkasa Bandung, 2005, h. 187-188.

${ }^{47}$ An-Nisa [4]: 4.

${ }^{48}$ Departemen Agama RI, Al-Qur'an, h. 364.

${ }^{49}$ Konsepsi adalah pembuahan benih; percampuran antara inti sel jantan dan inti sel betina. Lihat Tim Reality, KamusBiologi, h. 343.

${ }^{50}$ Mazhab adalah pendapat, paham, atau aliran seseorang alim besar dalam Islam yang digelari Imam, seperti Maẓhab Imam Hanafi dan Maẓhab Imam Syafi'i. Lihat Abdurrahman, Perbandingan Maẓhab, Bandung: Sinar Baru Algensindo, 2004, h. 8.

${ }^{51}$ Ahsin W. Alhafidz, Fikih Kesehatan, Jakarta: Amzah, 2010, h. 162.

${ }^{52}$ Ijma' adalah kesepakatan semua ulama mujtahid muslim dalam satu masa tertentu, setelah wafatnya Rasulullah Saw yang berkaitan dengan hukum syara'. Lihat Abd. Rahman Dahlan, UshulFiqh, Jakarta: Amzah, 2011, h. 146.

${ }^{53}$ Ahmad bin Ali bin Hajar al-Asqalani, Fathul Baari Juz 11, t.tp., Dar al-Fikr, t.t., h. 477. 
Artinya: Telah menceritakan kepada kami Abul Walid, Hisyam bin Abdul Malik telah menceritakan kepada kami Syu'bah telah memberitakan kepadaku Sulaiman Al A'masy mengatakan, saya mendengar Zaid bin Wahab dari Abdullah mengatakan, telah menceritakan kepada kami Rasulullah shallallahu 'alaihi wasallam seorang yang jujur lagi di benarkan, bersabda: "Sungguh salah seorang diantara kalian dihimpun dalam perut ibunya selama empat puluh hari, kemudian menjadi segumpal darah juga seperti itu, kemudian menjadi segumpal daging juga seperti itu, kemudian Allah mengutus malaikat dan diperintahkannya dengan empat hal, rejekinya, ajalnya, sengsara ataukah bahagia, demi Allah, sungguh salah seorang diantara kalian, atau sungguh ada seseorang yang telah mengamalkan amalan-amalan penghuni neraka, sehingga tak ada jarak antara dia dan neraka selain sehasta atau sejengkal, tetapi takdir mendahuluinya sehingga ia mengamalkan amalan penghuni surga sehingga ia memasukinya. Dan sungguh ada seseorang yang mengamalkan amalan-amalan penghuni surga, sehingga tak ada jarak antara dia dan neraka selain sehasta atau dua hasta, lantas takdir mendahuluinya sehingga ia melakukan amalan-amalan penghuni neraka sehingga ia memasukinya." Sedang Adam mengatakan dengan redaksi 'kecuali tinggal sehasta'. 54

Riwayat lain dalam ShahihMuslim disebutkan:

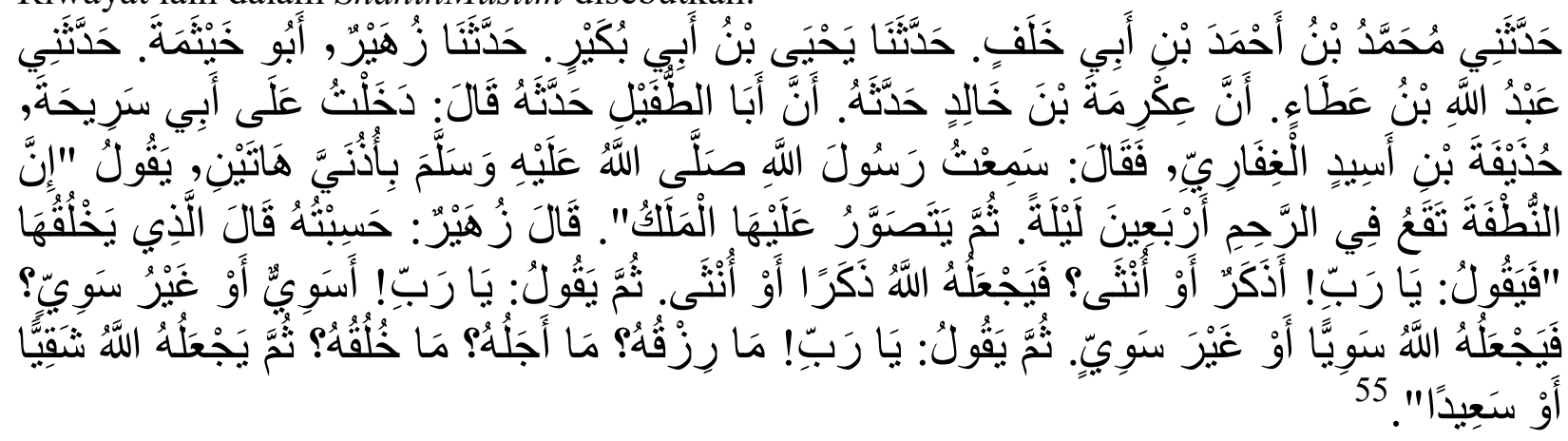

Artinya: Telah menceritakan kepadaku Muhammad bin Ahmad bin Abu Khalaf; Telah menceritakan kepada kami Yahya bin Abu Bukair; Telah menceritakan kepada kami Zuhair Abu Khaitsamah; Telah menceritakan kepadaku 'Abdullah bin 'Athaa bahwa 'Ikrimah bin Khalid; Telah menceritakan kepadanya bahwa Abu Ath Thufail Telah menceritakan kepadanya dia berkata; Aku menemui Abu Sarihah Hudzaifah bin Asid Al Ghifari lalu dia berkata; Aku mendengar dengan kedua telingaku ini Rasulullah shallallahu 'alaihi wasallam bersabda: Sesunggunya nuthfah disimpan di dalam rahim setelah empat puluh malam. Lalu datanglah malaikat -aku kira beliau berkata; yang akan membentuknya seraya berkata; Ya Rabb, apakah dia laki-laki atau perempuan? Lalu Allah menjadikannya laki-laki atau perempuan. Kemudian malaikat itu berkata; Ya Rabb, apakah dia menyimpang ataukah tidak? Lalu Allah menetapkan dia

\footnotetext{
${ }^{54}$ Terjemahan Kutub at-Tis'ah. Lihat juga Ibnu Hajar Al Asqalani, Fathul Baari 32: Shahih Bukhari, alih bahasa Amir Hamzah, Jakarta: Pustaka Azzam, 2009, h. 2-3.

${ }^{55}$ Abi al-Husaini Muslim bin Hajar al-Qusyairi an-Nisaburi, Shahih Muslim Jilid 2, Bairut: Dar al-Fikr, 2011, h. 550 .
} 
menyimpang dan tidaknya. Lalu malaikat berkata; Ya Rabb, bagaimana rizkinya, ajalnya, akhlaknya? Kemudian Allah menetapkan dia bahagia atau celaka. ${ }^{56}$

Huzaemah Tahido dalam bukunya Fikih Perempuan Kontemporer mengatakan bahwa ulama yang membolehkan aborsi sebelum janin berumur empat bulan adalah Muhammad Ramli dalam kitabnya Al-Nihayah. Alasannya karena belum ada mahluk yang bernyawa. Sedangkan ulama yang melarang aborsi ialah Ibnu Hajar dalam kitabnya At-Tuhfah, Al-Ghazali dalam kitabnya Ihya' Ulumuddin, dan Syekh Syaltut dalam kitab Al-Fatwa. Mereka melarang aborsi sebelum ditiupkan ruh karena sesungguhnya janin (embrio) pada saat itu sudah ada kehidupan yang patut dihormati. Tindakan aborsi pada tahap pertumbuhan kandungan merupakan jinayah. Makin meningkat usia kandungan akan semakin meningkat juga jinayahnya. ${ }^{57}$

Ulama empat mazhab berbeda pendapat mengenai masalah ini. Mazhab Hanafi membolehkan aborsi sebelum peniupan ruh yakni sebelum 120 hari usia kehamilan. Ulama Hanafiyah berpendapat bahwa benda yang tidak memiliki ruh, tidak akan dibangkitkan pada hari kiamat. Karena itu, aborsi dibolehkan sebelum peniupan ruh. ${ }^{58}$ Mazhab Hambali juga membolehkan aborsi sebelum peniupan ruh. Namun berbeda dengan mazhab Hanafi, yaitu bolehnya melakukan aborsi sebelum 40 hari usia kehamilan. ${ }^{59}$ Maz̧hab Syafi'i juga termasuk yang membolehkan aborsi sebelum peniupan ruh. Namun hukumnya terbagi menjadi dua yaitu, aborsi yang dilakukan mendekati peniupan ruh hukumnya makruh, sedangkan setelah peniupan ruh hukumnya haram. ${ }^{60}$

Maẓhab Maliki merupakan satu di antara empat maz̧hab yang mengharamkan aborsi secara mutlak. Menurutnya aborsi tidak dibolehkan bahkan sebelum janin berusia empat puluh hari. Lebih lanjut mazhab Maliki mengkategorikan aborsi setelah penyawaan sebagai bentuk kejahatan yang terkutuk. Tidak peduli apakah kandungan tersebut hasil dari perkawinan yang sah atau hubungan zina. Kecuali jika aborsi dilakukan untuk menyelamatkan nyawa ibu. ${ }^{61}$

Mahmud Syaltut dalam bukunya Al-Fatwa yang dikutip oleh Masyfuk Zuhdi mengatakan bahwa sejak bertemunya sel sperma dengan ovum, maka pengguguran kandungan merupakan suatu kejahatan dan haram hukumnya. Meskipun janin belum diberi nyawa, tetapi sudah ada kehidupan pada kandungan yang sedang mengalami pertumbuhan dan persiapan untuk menjadi mahluk baru yang bernyawa bernama manusia yang harus dihormati dan dilindungi eksistensinya. Tetapi apabila pengguguran kandungan itu dilakukan karena benar-benar terpaksa untuk menyelamatkan ibu, maka dibolehkan. Dalam hal ini eksistensi ibu lebih diutamakan daripada janin. ${ }^{62}$

Kehidupan dalam konsep Islam adalah suatu proses yang sudah dimulai sejak terjadinya pembuahan. Oleh sebab itu, pengguguran (aborsi) sejak pembuahan adalah haram hukumnya.

\footnotetext{
${ }^{56}$ Terjemahan Kutub at-Tis'ah. Lihat juga Imam Abu Husein Muslim, Shahih Muslim Juz IV, alih bahasa Adib Bisri Mustofa, Semarang: Asy Syifa', 1993, h. 573.

${ }^{57}$ Huzaemah Tahido Yanggo, Fikih Perempuan Kontemporer, Bogor: Ghalia Indonesia, 2010, h. 33. Lihat juga Muhammad Iqbal al-Haetami, MarriedByAccident, Depok: QultumMedia, 2004, h. 145. Dan M. Ali Hasan, Masail Fiqhiyah, h. 52.

${ }^{58}$ Maria Ulfah Anshor dan Abdullah Ghalib, Fiqih Aborsi, Jakarta: Fatayat NU dan The Ford Foundation, 2004, h. 34-35.

${ }^{59}$ Ibid., h. 38.

${ }^{60} \mathrm{Ibid}$., h. 43. Bandingkan dengan Ahmad al-Mursi H.J., Maqashid Syariah, alih bahasa Khikmawati, Jakarta: Amzah, 2009, h. 36.

${ }^{61}$ Maria Ulfah, Fiqh Aborsi, h. 36. Bandingkan dengan Ahmad al-Mursi, Maqashid Syariah, h. 36.

${ }^{62}$ Masfuk Zuhdi, Masail Fiqhiyah, h. 81. Lihat juga Kutbuddin Aibak, Kajian Fiqh Kontemporer, Yogyakarta: Teras, 2009, h. 90.
} 
Makin besar kandungan, makin besar pula jinayahnya, semakin besar pula dosanya. Apalagi setelah janin bernyawa dilakukan aborsi dan terlebih lagi membunuhnya setelah lahir, meskipun bayi itu hasil hubungan gelap (di luar perkawinan yang sah), karena setiap anak yang lahir dalam keadaan suci (tidak berdosa). ${ }^{63}$

Yusuf al-Qaradhawi dalam bukunya Fatwa-Fatwa Kontemporer mengatakan bahwa semenjak bertemunya sel sperma laki-laki dan sel telur perempuan, yang dari keduanya muncul mahluk baru dan menetap di dalam tempatnya yang kuat di rahim. Maka makhluk tersebut harus dihormati, meskipun ia merupakan hasil dari hubungan yang haram seperti zina. Rasulullah Saw telah memerintahkan wanita Ghamidiyah yang mengaku telah berbuat zina dan akan dijatuhi hukuman rajam itu agar menunggu sampai melahirkan anaknya, kemudian menunggu lagi sampai anaknya sudah tidak menyusu lagi barulah dijatuhi hukuman rajam. ${ }^{64}$ Dalil $^{65}$ yang digunakan Al-Qaradhawi ialah sebagai berikut:

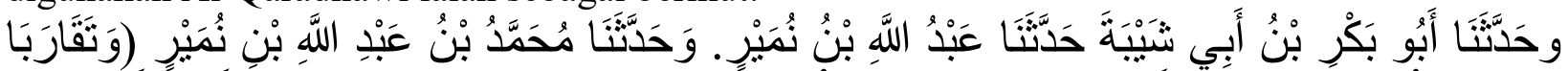

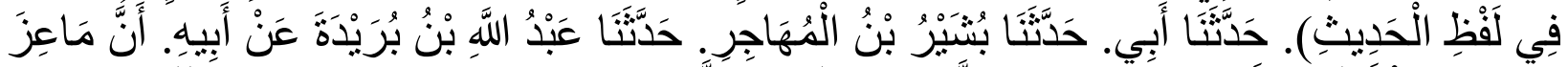

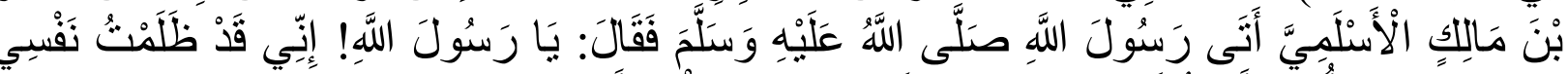

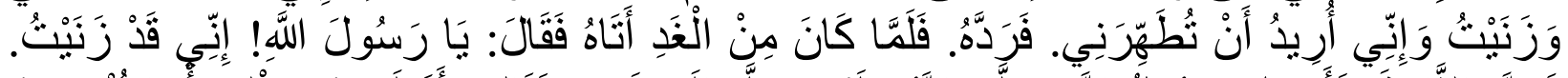

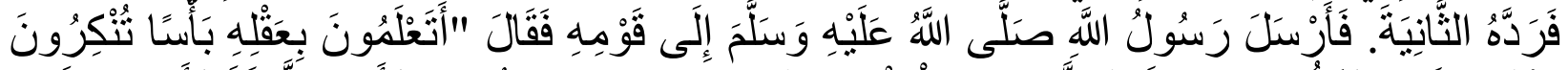

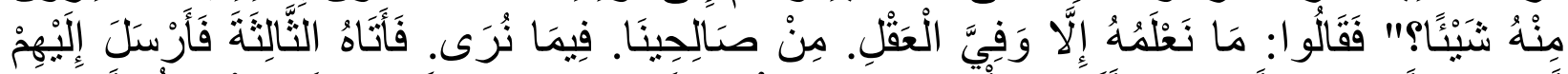

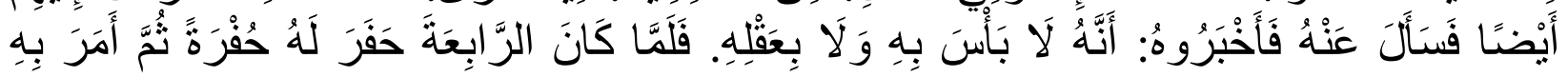

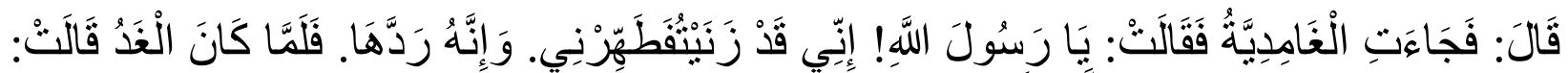

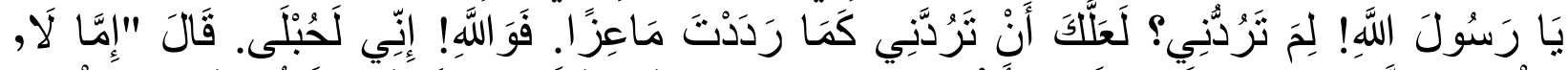

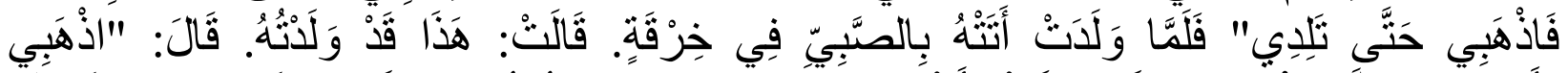

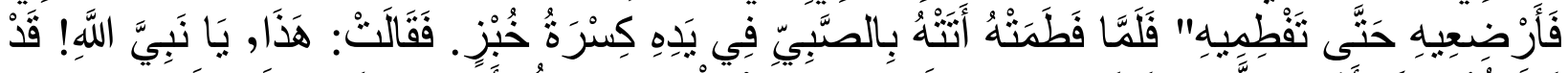

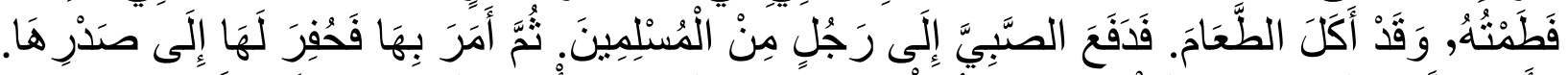

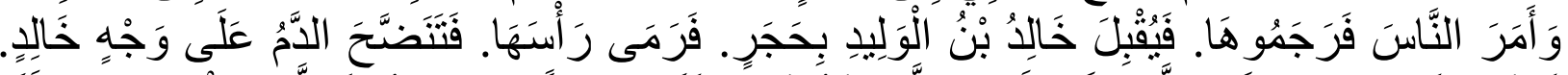

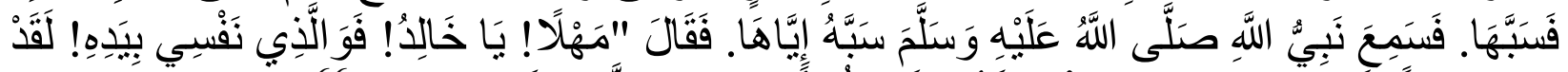

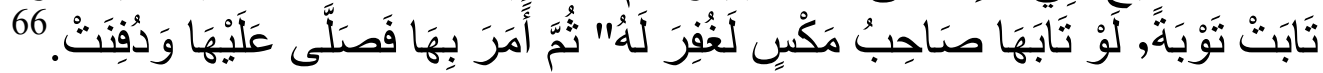

Artinya: Bersumber dari Abdullah bin Buraidah, dari ayahnya; sesungguhnya Ma'iz bin Malik Al Aslami datang menghadap Rasulallah s.a.w. dan berkata: "Wahai Rassulallah, sesungguhnya aku telah berbuat aniaya terhadap diriku sendiri. Aku telah melakukan perbuatan zina. Dan aku ingin sekali Anda berkenan membersihkan diriku yang kotor

${ }^{63}$ Huzaimah Tahido Yanggo, Masail Fiqhiyah: Kajian Hukum Islam Kontemporer, Bandung: Angkasa Bandung, 2005, h. 195.

${ }^{64}$ Yusuf al-Qhardhawi, Fatwa-Fatwa Kontemporer 2, alih bahasa As'ad Yasin, Jakarta: Gema Insani, 1995, h. 879 .

${ }^{65}$ Dalil adalah cara-cara yang ditempuh melalui ijtihad untuk menemukan hukum Islam. Lihat Abd. Rahman, Ushul Fiqh, h. 114.

${ }^{66}$ Abi al-Husaini Muslim bin Hajar al-Qusyairi an-Nisaburi, Shahih Muslim Jilid 2, Bairut: Dar al-Fikr, 2011, h. 112 . 
ini”. Tetapi Rasulallah s.a.w. menolak permintaan itu. Pagi harinya, Ma'iz bin Malik datang menghadap lagi. Dia berkata: "Wahai Rasulallah, sesungguhnya aku telah berbuat zina." Untuk yang kedua kalinya Rasulallah s.a.w. menolak pengakuannya tersebut. Beliau lalu menyuruh seorang kurir untuk menemui kaumnya Ma'iz bin Malik. Beliau titip pesan lewat kurir itu yang isinya: "Apa pendapat kalian jika aku beritahukan kepada kalian bahwa ada yang tidak beres pada pikiran Ma'iz bin Malik? Aku yakin kalian tentu merasa senang dengan apa yang diperbuatnya". Selanjutnya mereka membalas pesan beliau tersebut: "Kami yakin kalu Ma'iz bin Malik itu terganggu pikirannya. Setahu kami, dia adalah orang yang baik di antara kami."

Dan untuk yang ketiga kalinya Ma'iz datang lagi kepada Rasulallah s.a.w. kemudian beliau kembali menyuruh seorang kurir untuk menemuin kamunya Ma'iz bin Malik. Beliau bertitip pesan kepada mereka bahwa tidak ada yang tidak beres pada pikirian Ma'iz bin Malik. Ketika untuk keempat kalinya Ma'iz bin Malik datang kepada Rasulullah s.a.w. dengan maksud yang sama, maka dibikinlah sebuah lubang galian untuk menghukum pancung Ma'iz. Kemudian beliau menyuruh utnuk menghukum Ma'iz, dan hukuman pun dilaksanakan.”

Seterusnya Abdullah bin Buraidah mengatakan: "Suatu ketika ada seorang perempuan Ghamidiyah datang kepada Rasulullah s.a.w. ia mengatakan: Wahai Rasulullah, sesungguhnya aku telah berbuat zina. Maka bersihkanlah diriku yang kotor ini." Tetapi Rasulullah s.a.w. menolak pengakuannya. Esoknya, perempuan itu datang lagi menemui Rasulullah, mengapa Anda menolak pengakuanku? Mungkin alasan Anda menolak aku adalah sama seperti ketika Anda menolak pengakuan Ma'iz bin Malik. Demi Allah, sesungguhnya sekarang aku ini sedang hamil." Rasulullah s.a.w. bersabda: "Mungkin tidak. Sekarang pulanglah, sampai kamu melahirkan". Setelah melahirkan, wanita tersebut datang lagi kepada Rasulullah s.a.w. dengan membawa bayi laki-laki yang dibungkus dengan secarik kain. Ia berkata: "Bayi inilah yang telah aku lahirkan." Beliau bersabda: "Pulanglah, dan susuilah sampai kami menyapihnya." Setelah memasuki masa menyapih, wanita itu datang lagi kepada Rasulullah s.a.w. dengan membawa bayinya dan di tangannya terdapat sepotong roti. Ia berkata: "Wahai Rasulullah, sesungguhnya bocah ini telah aku sapih dan dia sudah bisa menikmati makanan sendiri." Akhirnya Rasulullah s.a.w. menyerahkan bocah tersebut kepada salah seorang lelaki kaum muslimin. Selanjutnya beliau menyuruh untuk mengatasi wanita itu. Ia ditanam ke tanah sampai sebatas dada. Selanjutnya beliau menyuruh orang-orang untuk melemparinya dengan batu. Percikan darah dari wanita itu sampai mengenai wajah Khalid, sampai-sampai si Khalid mencaci-maki wanita tersebut. Ketika caci-maki tersebut didengar oleh Rasulullah s.a.w. bersabda: "Tenanglah, wahai Khalid. Demi Dzat yang jiwaku berada dalam genggaman tangan-Nya, wanita itu telah bertaubat dengan sungguh-sungguh. Siapapun yang mau bertaubat dengan sungguh-sungguh sekalipun dia seorang penarik pajak secara tidak halal, maka dia tentu akan diampuni”. Setelah didapati meninggal dunia, Rasulullah s.a.w. lalu menyuruh untuk mengurus jenazahnya. Setelah menyembahyanginya, beliau kemudian ikut memakamkannya." ${ }^{67}$

Hadis di atas memberikan pemahaman akan larangan aborsi. Dalam hal ini digunakan metode dalam ushul fikih yaitu mafhūm mukhālafah. Menurut Amir Syarifuddin, mafhūm

\footnotetext{
${ }^{67}$ Imam Abu Husein Muslim, Shahih Muslim Juz III, alih bahasa Adib Bisri Musthofa, Semarang: Asy-Syifa, 1993, h. 298-299.
} 
mukhālafah adalah mafhūm ${ }^{68}$ yang lafażnya menunjukkan bahwa hukum yang tidak disebutkan berbeda dengan hukum yang disebutkan. ${ }^{69}$ Dalam istilah ilmu hukum modern metode ini dikenal dengan metode penafsiran a contrario. ${ }^{70}$

Rasulullah Saw dalam hadis di atas, melakukan penundaan eksekusi hukuman rajam kepada wanita yang tengah hamil. Bahkan penundaannya sampai bayi yang dilahirkannya disapih. Mafhüm mukhālafahnya ialah jika wanita tersebut tidak sedang hamil, maka eksekusi hukuman rajam tidak akan ditunda. Sehingga dapat dipahami, hadis ini menujukkan untuk memertahankan eksistensi bayi dalam kandungan. Meskipun kehamilan dari hasil zina, tetap saja bayi tersebut merupakan makhluk yang suci, yang terbebas dari keselahan dan dosa orang tuanya.

Sayyid Sabiq berpendapat bahwa perempuan yang hamil tidak boleh dirajam. Hukumannya harus ditunda sampai ia melahirkan dan menyusui anaknya. ${ }^{71}$ Hal ini memberikan pemahaman bahwa dalam kondisi apapun, jika janin tidak membahayakan ibunya maka janin tersebut tidak dibenarkan jika diaborsi.Syaikh Muhammad Mutawwali yang dikutip oleh Ahmad al-Mursi dalam bukunya Maqashid Syariah mengatakan:

Kita tidak menyaksikan penciptaan makhluk, namun setiap hari kita menyaksikan kematian, dan hal ini merupakan hal yang sudah kita ketahui bersama. Merusak segala sesuatu berarti kebalikan dari menciptakannya. ...jadi, kematian adalah kebalikan kehidupan karena ia merusak kehidupan. Maka bagaimana manusia diperkenankan merusak sesuatu yang dibangun (diciptakan) Allah? ${ }^{72}$

Al-Qaradhawi lebih lanjut mengatakan bahwa dalam kasus aborsi korban perkosaan hendaknya perempuan tersebut memelihara janinnya. Dalam hal ini masyarakat muslim sudah seharusnya mengurus pemeliharaan dan nafkah anak tersebut serta memberinya pendidikan yang baik, jangan menyerahkan beban itu kepada ibunya yang telah terkena cobaan. Demikian juga pemerintah, seharusnya bertanggung jawab terhadap pemeliharaan ini melalui departemen sosial tertentu. $^{73}$

Aliba'ul Chusna memiliki pemikiran yang sejalan dengan Al-Qaradhawi. Di dalam Jurnalnya yang berjudul Aborsi dan Hak Atas Pelayanan Kesehatan dikatakan bahwa "aborsi dengan alasan hamil hasil perkosaan atau hubungan di luar nikah juga tidak dibenarkan, karena Islam menganggap hal tersebut bukanlah suatu penyelesaian". ${ }^{74}$

Aborsi memiliki dampak negatif bagi pelakunya. Sehingga menjadi suatu pertimbangan hukum juga, karena jika dilakukan aborsi akan memberikan dampak negatif. Dampak tersebut ialah sebagai berikut:

1. Fisik

${ }^{68}$ Mafhūm, adalah sesuatu yang ditunjuk oleh lafaż, tetapi bukan dari ucapan lafaż itu sendiri. Lihat, Nazar Bakry, Fiqh dan Ushul Fiqh, Jakarta: RajaGrafindo Persada, 2003, h. 179.

${ }^{69}$ Amir Syarifuddin, Ushul Fiqh Jilid 2, Jakarta: Kencana, 2009, h. 159. Lihat juga Khairul Umam dan Ahyar Aminudin, Ushul Fiqh II, Bandung: Pustaka Setia, 2001, h. 50.

${ }^{70}$ Penafsiran a contrario, adalah suatu cara menafsirkan undang-undang yang didasarkan pada perlawanan pengertian antara soal yang dihadapi dan soal yang diatur dalam suatu pasal undang-undang. Lihat C.S.T. Kansil, Pengantar Ilmu Hukum Jilid 1, Jakarta: Balai Pustaka, 2002, h. 39. Lihat juga Sudikno Mertokusumo, Mengenal Hukum (Suatu Pengantar), Yogyakarta: Liberty Yogyakarta, 2003, h. 180-182.

${ }^{71}$ Sayyid Sabiq, Fiqih Sunnah 4, alih bahasa Abu Syauqina dan Abu Aulia Rahma, t.tp., Tinta Abadi Gemilang, 2013, h. 151.

${ }^{72}$ Ahmad al-Mursi, Maqashid Syariah, h. 25.

${ }^{73}$ Yusuf al-Qhardhawi, Fatwa-Fatwa, h. 881.

${ }^{74}$ Aliba'ul Chusna, “Aborsi dan Hak, h. 99. 
a. Kematian mendadak karena pendarahan hebat.

b. Kematian mendadak karena pembiusan yang gagal.

c. Kematian akibat infeksi serius di sekitar kandungan.

d. Rahim yang robek (uterine perforation).

e. Kerusakan leher rahim (cervical lacerations) yang dapat menyebabkan cacat pada anak berikutnya.

f. Kanker payudara karena ketidak-seimbangan hormon estoregon dan kanker indung telur (ovarium cancer).

g. Kanker leher rahim (cervical cancer).

h. Kanker hati (liver cance).

i. Kelainan pada ari-ari (placenta previa) yang dapat menyebabkan cacat pada anak berikutnya dan pendarahan hebat pada saat kehamilan berikutnya.

j. Menjadi mandul (ectopic pregnancy)

$\mathrm{k}$. Infeksi rongga panggul (pelvic inflammatory disease).

1. Infeksi pada lapisan rahim (endometriosis).

2. Psikologis

Aborsi selain berdampak pada fisik ibu, dapat juga berdampak pada psikologisnya. Dampak ini tidak bisa dianggap remeh setelah aborsi dilakukan. Terdapat suatu sindrom yang bernama post-abortion syndrome. Gejala-gejalanya ialah timbul rasa kehilangan harga diri, senantiasa mimpi buruk, histeris, dan munculnya perasaan bersalah yang berkepanjangan. ${ }^{75}$

Aborsi memang perlu disikapi dengan hati-hati, mengingat dampak yang akan ditimbulkan berbahaya. Meskipun dalam PP/61/2014 telah mengatur bahwa pelaksanaan aborsi aman dan bermutu. Sebagaimana ditentukan dalam Pasal 35 ayat (1): "aborsi berdasarkan indikasi kedaruratan medis dan kehamilan akibat perkosaan harus dilakukan dengan aman, bermutu, dan bertanggung jawab". ${ }^{76}$

Kehamilan akibat perkosaan merupakan kehamilan hasil perbuatan zina. Perkosaan merupakan perbuatan asusila yang dilakukan atas kemauan salah satu pihak saja, dan perempuannya dalam posisi korban. Maka perempuan tersebut tidak terkena hukuman zina, yang terkena hukuman hanya laki-lakinya. ${ }^{77}$ Dalam hal ini, perempuan korban perkosaan tersebut merasakan trauma psikologis, yakni rasa sangat malu akan kandungannya. Menurut hukum Islam, trauma psikologis tersebut tidak dapat menjadi dasar dibolehkannya aborsi. Karena derajatnya tidak sampai kepada tingkatan aḍ-daruriyat yang akan mengakibatkan kematian. Sehingga, ditinjau dari hukum Islam, aborsi akibat perkosaan hukumnya tidak diperkenankan. Karena tidak terwujudnya maqāșid syarīah, yaitu pemeliharaan jiwa (hifạunafs) dan pemeliharaan keturunan (hifžunasl).

\section{Kesimpulan}

PP/61/2014 menentukan bolehnya aborsi akibat perkosaan karena korban perkosaan mengalami trauma psikologis. ketentuan ini memiliki persyaratan usia kehamilan paling lama 40 hari yang dibuktikan dengan surat keterangan dokter, penyidik, psikolog dan/atau ahli lainnya. Penyelenggaraan aborsi harus dilakukan dengan aman, bermutu, dan bertanggung jawab, serta

\footnotetext{
${ }^{75}$ Ibid., h. 104-105.

${ }^{76}$ Himpunan Peraturan Perundang-Undangan, h. 132.

${ }^{77}$ Imam Abu Hanifah dan Imam Syafi'i berpendapat bahwa timbulnya kehamilan dan pengakuan telah dipaksa menyebabkan tidak dilaksanakannya hukuman terhadap orang perempuan tersebut. Lihat Ibnu Rusyd, Bidayatul Mujtahid Jilid 3, alih bahasa Abdurrahman, Semarang: Asy-Syifa, 1990, h. 633. Lihat juga Irma Riyani, "Menimbang Kembali, h. 3-4.
} 
setiap pelaksanaan aborsi wajib dilaporkan kepada kepala Dinas Kesehatan kabupaten/kota dengan tembusan kepada kepala Dinas Kesehatan provinsi.

Aborsi akibat perkosaan dalam PP/61/2014 ditinjau dari hukum Islam melalui maqāșid syarīah hukumnya tidak diperbolehkan, karena tidak terpeliharanya dua di antara lima unsur pokok maqāșid syarīah, yaitu pemeliharaan jiwa (hifẓunafs) dan pemeliharaan keturunan (hifzunasl). Selain itu, ketentuan ini juga melanggar hak asasi manusia dan tidak mencerminkan keadilan, yang telah mengesampingkan hak-hak janin, padahal kemudaratan perempuan korban perkosaan tidak sampai pada tingkatan aḍ-daruriyat, hanya tingkatan al-hājizyat. 


\section{DAFTAR PUSTAKA}

Abdurrahman, Perbandingan Maz̧hab, Bandung: Sinar Baru Algensindo, 2004.

Al-Asqalani,Ahmad bin Ali bin Hajar,Fathul Baari Juz 11, t.tp., Dar al-Fikr, t.t..

Al-Asqalani,Ahmad bin Ali bin Hajar,Fathul Baari Juz 12, t.tp., Dar al-Fikr, t.t.

Al-Asqalani,Ibnu Hajar,Fathul Baari 32: Shahih Bukhari, alih bahasa Amir Hamzah, Jakarta: Pustaka Azzam, 2009.

Al-Asqalani,Ibnu Hajar,Fathul Baari 33: Shahih Bukhari, alih bahasa Amir Hamzah, Jakarta: Pustaka Azzam, 2009.

Al-Ghazali,Imam,Ihya'Ulumiddin Jilid 1, alih bahasa Ismail Yakub, Singapura: Pustaka Nasional PTE LTD, 1998.

Al-Haetami,Muhammad Iqbal,MarriedByAccident, Depok: QultumMedia, 2004.

Alhafidz,Ahsin W.,Fikih Kesehatan, Jakarta: Amzah, 2010.

Al-Mursi H.J.,Ahmad,Maqashid Syariah, alih bahasa Khikmawati, Jakarta: Amzah, 2009.

Al-Qhardhawi,Yusuf,Fatwa-Fatwa Kontemporer 2, alih bahasa As'ad Yasin, Jakarta: Gema Insani, 1995.

Amin,Ma'ruf dkk., Himpunan Fatwa Majelis Ulama Indonesia Bidang Sosial dan Budaya, Jakarta: Penerbit Erlangga, 2015.

Amiruddin dan Zainal Asikin, Pengantar Metode Penelitian Hukum, Jakarta: Rajawali Pers, 2010.

Anshor,Maria Ulfah dan Abdullah Ghalib, Fiqih Aborsi, Jakarta: Fatayat NU dan The Ford Foundation, 2004.

Ardiantofani,Chilmi, 2014, 30 Persen Kasus Aborsi di Jatim Pelakunya Remaja, Surabayanews.co.id/2014/08/18/3745/30-persen-kasus-aborsi-di-jatim-pelakunyaremaja.html (online 28 Oktober 2014).

Bakri,Asfari Jaya,Konsep Maqaid al-Syari'ah Menurut al-Syatibi, Jakarta: RajaGrafindo Persada, 1996.

Bakry,Nazar,Fiqh dan Ushul Fiqh, Jakarta: RajaGrafindo Persada, 2003.

Dahlan,Abd. Rahman,UshulFiqh, Jakarta: Amzah, 2011.

Departemen Agama Republik Indonesia, Al-Qur'an Dan Terjemahnya Juz 1-30 Edisi Baru, Jakarta: Pustaka Agung Harapan, 2006.

Departemen Pendidikan, Kamus Besar Bahasa Indonesia, Jakarta: Balai Pustaka, 2005.

Dimyati,Vien, 2012, BKKBN: Tiap Tahun , Kasus Aborsi meningkat 15 persen, www.jurnas.com/news/71467/BKKBN-tiap-tahun-kasus-aborsi-meningkat-15-persen-2012/1/sosial-budaya/ kesehatan (online 28 Oktober 2014).

Djazuli,A.,Kaidah-Kaidah Fikih: Kaidah-Kaidah Hukum Islam dalam Menyelesaikan MasalahMasalah yang Praktis, Jakarta: Kencana, 2007. 
Emzir, AnalisisData: Metodologi Penelitian Kualitatif, Jakarta: Rajawali Press, 2011.

Himpunan Peraturan Perundang-Undangan; Undang-Undang Kesehatan dan Kesehatan Jiwa, Bandung: Fokusmedia, 2014.

Ibnu Rusyd, Bidayatul Mujtahid Jilid 3, alih bahasa Abdurrahman, Semarang: Asy-Syifa, 1990.

Jumrodah, "Proses Penciptaan Manusia Menurut Pandangan Islam dan Embryologi", Jurnal Himmah, Palangka Raya: STAIN Palangka Raya, Vol. VII, No. 19, 2006.

Kansil,C.S.T.,Pengantar Ilmu Hukum Indonesia, Jakarta: Rineka Cipta, 2011.

Kansil,C.S.T.,Pengantar Ilmu Hukum Jilid 1, Jakarta: Balai Pustaka, 2002.

Mertokusumo,Sudikno,Mengenal Hukum (Suatu Pengantar), Yogyakarta: Liberty Yogyakarta, 2003.

Mubarok,Jaih,Kaidah Fiqh: Sejarah dan Kaidah-Kaidah Asasi, Jakarta: RajaGrafindo Persada, 2002.

Mudzhar,Mohammad Atho,Fatwa-Fatwa Majelis Ulama Indonesia; Sebuah Studi tentang Pemikiran Hukum Islam di Indonesia, alih bahasa Soedarsono, Jakarta: INIS, 1993.

Musbikin,Imam,Qawa'id al-Fiqhiyah, Jakarta: RajaGrafindo Persada, 2001.

Muslim,Abi al-Husaini bin Hajar al-Qusyairi an-Nisaburi, Shahih Muslim Jilid 2, Bairut: Dar alFikr, 2011.

Muslim,Abi al-Husaini bin Hajar al-Qusyairi an-Nisaburi, Shahih Muslim Jilid 2, Bairut: Dar alFikr, 2011.

Muslim,Imam Abu Husein, Shahih Muslim Juz III, alih bahasa Adib Bisri Musthofa, Semarang: Asy-Syifa, 1993.

Muslim,Imam Abu Husein,Shahih Muslim Juz IV, alih bahasa Adib Bisri Mustofa, Semarang: Asy Syifa', 1993.

Nyi S,Radian, 2014, Menkes Tegaskan PP 61/2014 tentang Kesehatan Reproduksi Tak legalkan Aborsi, http://health.detik.com/read/2014/08/19/162817/ 2666595/763/menkes-tegaskanpp-61-2014-tentang-kesehatan-reproduksi-tak-legalkan-aborsi(online 24 Oktober 2014)

Riyani,Irma, "Menimbang Kembali Hukum Aborsi Pada Kasus Kehamilan Akibat Perkosaan”, Jurnal Studi Agama dan Masyarakat, Palangka Raya: STAIN Palangka Raya, Vol. 2/No. 2, 2005.

Sabiq,Sayyid,Fiqih Sunnah 4, alih bahasa Abu Syauqina dan Abu Aulia Rahma, t.tp., Tinta Abadi Gemilang, 2013.

Soekanto,Soerjono dan Sri Mamudji, Penelitian Hukum Normatif, Jakarta: RajaGrafindo Persada, 2003.

Soesilo, KUHP (Kitab Undang-Undang Hukum Pidana) \& KUHAP (Kitab Undang-Undang Hukum Acara Pidana), Yogyakarta: Gama Press, 2008.

Syarifuddin,Amir, Ushul Fiqh Jilid 2, Jakarta: Kencana, 2009.

Tim Reality, KamusBiologi, Surabaya: Reality Publisher, 2009. 
Umam,Khairul dan Ahyar Aminudin, Ushul Fiqh II, Bandung: Pustaka Setia, 2001.

Undang-Undang R.I. Nomor 36 tahun 2009 tentang Kesehatan \& Undang-Undang R.I. Nomor 44 tahun 2009 tentang Rumah Sakit, Bandung: Citra Umbara, 2012.

Usman,Muhlish,Kaidah-Kaidah Istinbath Hukum Islam: (Kaidah-Kaidah Ushuliyah dan Fiqhiyah), Jakarta: RajaGrafindo Persada, 1995.

www.aborsi.org/statistik.html (online 28 Oktober 2014)

Yanggo,Huzaemah Tahido,Fikih Perempuan Kontemporer, Bogor: Ghalia Indonesia, 2010.

Yanggo,Huzaimah Tahido,Masail Fiqhiyah; Kajian Hukum Islam Kontemporer, Bandung: Angkasa Bandung, 2005.

Yunus,Mahmud,Kamus Arab-Indonesia, Jakarta: Mahmud Yunus Wadzurriyyah, 1990. 